原著論文

\title{
加齢・時勢・世代の要因からみたスポーツ参加の変動パターン†
}

\author{
山本 達 三* 菊池秀 夫** 中 村 隆***
}

\section{Classification of Changes in Sports and Recreational Activities Based on Age-period-cohort Analyses of Participation Rates ${ }^{\dagger}$}

\author{
Tatsuzo YAMAMOTO ${ }^{*}$, Hideo KIKUCHI ${ }^{* *}$ and Takashi NAKAMURA ${ }^{* * *}$
}

\begin{abstract}
This paper aims to classify changes in sports and recreational activities from 1982 to 2001 and to investigate future trends in the numbers of participants of various types of activities based on age-period-cohort analyses. The effects of age, period, and cohort on participation rates are estimated from data classified by age group and survey period using the Bayesian logit cohort model. A total of 50 activities for both sexes are classified into four clusters for age effects, five for period effects, and six for cohort effects using cluster analysis. The main results are : (1) From the clusters for age effects, people increase or keep their participation in some activities, while they disengage themselves from participation in many activities as they age. (2) From the clusters for period effects, participation in some activities such as golf are affected by the time trends related to household income, economic cycle, and fashion of comics. (3) From the clusters for cohort effects, each cohort tends to continue participation in particular activities depending on the historical circumstances where its members grew up.
\end{abstract}

Key words : Changes of Participation in Sports and Recreational Activities, Bayesian Logit Cohort Model, Age, Period, and Cohort Effects, Disengagement from Participation, Continuity of Participation

1.はじめに

近年, スポーツ政策の立案に有用な社会全体 のスポーツ参加に関するデータが蓄積され，ス ポーツ参加の趨勢が報告されてきている．例え ば，北米では，Kelly ら"がアメリカ合衆国のス ポーツに関する継続調査データを用いて, 我が 国では, 社会経済生産性本部（旧・余暇開発セ
ンター）が「余暇活動に関する調査」データを 用いてスポーツ参加の動向を報告している2)-5). 我が国のスポーツ参加の趨勢についてみる と, ジョギング・マラソンは安定であり, トレー ニングは微増傾向, 体操, ピクニック・ハイキ ング・野外散歩は微減傾向ながら,これらの健 康関連種目の参加率はその他の種目に対して高 い参加率を維持している. 一方, スキー, テニ

\footnotetext{
†原稿受付 2005 年 3 月 22 日

*愛知学泉大学 $\bar{T} 471-8532$ 愛知県豊田市大池町汐取 1

**中京大学 $\overline{7} 470-0393$ 愛知県豊田市貝津町床立 101

***統計数理研究所 个106-8569 東京都港区南麻布 4-6-7

*Aichi Gakusen University, 1, Shiotori, Oike, Toyota, Aichi, Japan (471-8532)

** Chukyo University, 101, Tokodachi, Kaizu, Toyota, Aichi, Japan (470-0393)

${ }^{* * *}$ The Institute of Statistical Mathematics, 4-6-7, Minami Azabu, Minato, Tokyo, Japan (106-8569)
} 
ス, 野球, ソフトボール, バレーボール, バス ケットボール，水泳，ゴルフ練習場など大半の 種目の参加率は 1993 年頃をピークに減少傾向 にある.

ところで, 上記のような単純集計の時系列分 析による趨勢の記述に止まるのではなく，さら にその先を追究することが必要である，なぜな ら, 単純集計の時系列データには加齢・時勢・ 世代差, さらには人口の年齢構成の変化の影響 が混交しているからである．経年的な変動は小 さく安定していても加齢に伴うスポーツ参加率 の低下が背後に隠れているかもしれない，流 行, 景気変動, 労働状況の変化などの時勢の影 響がスポーツ参加率を変動させているかもしれ ない. あるいは，世代別の参加率は変化しにく いが世代差があるために，世代交代によって社 会全体の参加率が低下（増加）しているかもし れないのである. また, 3 要因以外にも少子高 齢化のような人口の年齢構成の変化（以下「人 口変動」）がスポーツ参加人口に大きく影響を 与えていることも考えられる.

スポーツ参加の変動に対する加齢, 時勢, 世 代差の影響が解明できれば, 各スポーツ種目の スポーツ人口（注 1) が, これまで 3 つの要因 の影響をどのように受けてきたか，また今後 変化するであろう方向性をもある程度予測する こと ${ }^{6)-9)}$ ができる. そしてこれらに基づいて, 国や地域コミュニティにおけるスポーツ政策, 公共スポーツ施設の設置, 施設やサービスの効 率的な運用，スポーツ・レジャーに関わる企業 戦略などにおいて, 将来の種目毎のスポーツ参 加の動向やスポーツ人口を見据えたプランニン グが可能になる.

我々は先に，4 時点の継続調査デ一夕を用い て, バスケットボール, エアロビクスについて 参加率の変動を年齢・時代・コウホート（注 2 )の3 効果に分離した結果を報告してきた ${ }^{6) 7)}$. また, ゴルフを例示として, 得られた 3 効果の 推定值に基づき人口変動を考慮するスポーツ人 口の推定・予測方法を提示してきた ${ }^{8)}$. さらに ゴルフ以外の 23 種目についても, コウホートモ
デルにおける最適モデルおよびその年齢・時代・ コウホート効果の推定結果を報告してきた ${ }^{9}$.

以上を踏まえ新たに本稿では, デー夕時点数 を 20 時点に増やしたデータセット（1982 年〜 2001 年）を用いて, ベイズ型ロジット・コウ ホートモデルにより 25 種目のスポーツ参加率 について年齢・時代・コウホート効果を分離し, 得られた各効果の推定值に基づいて 25 種目男 女別のスポーツ種目をクラスター分析によりパ ターン (類型) 化した. 得られた結果から, 我 が国全体のスポーツ参加の変動が 3 要因のいず れによって強い影響を受け, どのように変化し ているのかを明らかにし, スポーツ参加の今後 の大まかな動向についても述べる.

\section{2. 研究の背景}

加齢の側面からの研究では, 運動・スポーツ 参加率は加齢とともに減少する, もしくは加齢 に反比例する ${ }^{10)-17)}$ とした言及が長らくなされ てきた. しかし近年, 加齢とともに参加が低下 するとした従来の所見以外に, 時代の変遷や世 代の要因から, スポーツに参加する意図, 態 度, 行動が変化してきたとする解釈がみられる ようになってきている. 例えば, [1] 同一時点 の年齢間比較から年齢によってスポーツ活動を 開始・中止・代替・継続する割合に特定の傾 向があるとする Jackson ら ${ }^{18)}$, Searle ら ${ }^{19)}$, IsoAhola $ら^{20)}$, Strain $5^{21)}$ の研究, [2] 2 点間のデー 夕比較から, より新しい世代では, 中高年に達 した時点での参加頻度をみると, 非実施層が増 加すると同時に定期的実施層も増加するという スポーツ参加の二極化が進むことを示す Curtis $ら^{13)}$ や長ヶ原 ${ }^{22)}$ の研究, [3] スポーツ活動の参 加態度に加齢だけでなく世代の要因が関連して いる可能性を示唆する高峰ら ${ }^{23)}$ の研究, [4] ク ロスセクションでは高齢になるほどスポーツ参 加率は低下するという傾向は依然として存在す るが，低年齢層と高齢層の差は縮まってきてい るとして世代の影響を示唆する勝浦 ${ }^{24)}$ の報告, などである.

時勢の側面からの研究では, 継続調査データ. 
経年データの不足から, 豊富な研究がなされて きたとは言えないが, 運動・スポーツ参加は景 気や流行などの時勢の影響を受けるとする言 及がなされてきた. 例えば, [1]フィッシング とハンティング参加率の変化は，1 人当たり所 得（per-capita income）（注 3）などのような外 的要因の時勢と相関が高いことを示した Brown ら ${ }^{25)}$ の研究, [2] フィッシングとハンティング の各年齢階級の参加率は, 5 年間隔 6 時点のデー 夕によると安定しているが, 時勢の影響からハ ンティング人口は減少し, フィッシング人口は 増加することを示唆した Snepenger $5^{26)}$ の研究, [3]レクリエーション参加は景気循環 (Economic Cycle）などの時勢の影響と関連があることを 示唆した Foot $5^{27)}$ の研究, [4] 総務庁統計局に よる社会生活基本調查を用いて, スポーツ参加 率の変化は加齢の要因以外に時勢や世代の影響 を受けていることを示唆した永山到, 勝浦 $^{24)}$ の 報告, [5] 北米のスポーツ参加に関する年齢階 級別参加率の時系列的変化に関する Kelly $5^{1)}$ の報告, [6] 社会経済生産性本部（旧・余层開 発センター）による種目別スポーツ参加率の単 純集計時系列 ${ }^{2)-5)}$, などである.

世代 (コウホート) の側面からの研究では, ある時点の高齢者層などに過去に遡ってスポー ツ参加について質問し, 同一コウホートの参加 パターンの経時比較をおこなつた研究 ${ }^{29)-33)}$ が なされてきた. しかし, サンプルはある調査時 点の一定年齢以上の人口ではなく高齢者世代に 限られているため, 得られた参加パターンは社 会全体に適用することはできないことが指摘さ れてきた ${ }^{31)}$. また, 1 時点の調査デ一タからス ポーツ参加に対する加齢・時勢・世代の違いを 区別することができないのも自明である ${ }^{8)}$ ， そ こで, 社会全体のスポーツ参加に対する 3 要因 の各側面からではなく, 時勢・加齢” 世 世代の違 いの 3 つの要因を同時に考慮して社会全体のス ポーツ参加の変動を捉えようとする試みも, 僅 かではあるがなされている. 例えば, [1]体力ス ポーツに関する世論調査の継続調査デー夕の年 齢別スポーツ参加率を用いて, 同一年齢層の時
点間変動と同一コウホート（世代）内変動の差 から, 時勢や世代固有の特徵がスポーツ参加率 の変動に関連している可能性と, かならずしも 加齢とともに参加率が低下するわけではない可 能性を推論した海老原 ${ }^{34)}$ の報告, [2] パネルデー 夕を用いて, 年齢間の比較 (cross-sectional age differences), 加齢による変化 (longitudinal age changes), 時勢の変化 (secular changes across time periods）から, 加齢によりスポーツ・レジャーに費 やす 1 日当たりの活動時間は減少すること, 若い 世代の男性のレジャーやスポーツに費やす時間が 増加していることなどを示唆した Verbrugge ら ${ }^{35)} の$ 研究, [3] 65 歳以上の高齢者の 1985, 1990, 1995 年の 3 時点の身体活動データから, ウォーキング, 自転車の参加率と平均活動時間を分析し, 加齢 とともに活動時間が減少すること, 観察した世代 間では身体活動に有意な差はないことを示唆した Bijenen 5 ${ }^{36)}$ の研究， [4] 1986，1991，1996 年の 3 時 点の継続調査データを用いて作成したコウホート 表や図をもとに, 野球, ゴルフ, テニスなどについ て年齢・時代・コウホート効果の有無やその大き さについて推論している寺崎 ${ }^{377}$ の研究, などである.

以上のように, 加齢, 時勢, 世代のそれぞれ の側面からなされた研究では, 複数の解釈が成 立してきたが, その背景には, 用いられた研究 データに加齢・時勢・世代の 3 つの要因が一次 従属の関係にあること（識別問題）（注 4）が ある.つまり，用いられたデータには加齢・時 勢・世代要因の影響が混交しているが，いずれ の研究においても，3つの要因の効果を識別せ ずに, 各側面からのみ解釈がおこなわれてきた からである. したがって加齢, 時勢, 世代要因 の影響, すなわち, 年齢・時代・コウホート効 果を区別できれば，従来，様々な解釈がなされ てきたスポーツ参加の変動と 3 つの要因との関 係を明らかにすることができ, 各効果の大きさ がどの程度なのか, 各効果と外的要因との関連 などを分析することが可能となる ${ }^{8)}$. 具体的に は, データの変動が年齢効果（各成員の加齢に よる変化）によることがわかれば，社会の成員 の意見や態度は加齢に伴って変化するが, 社会 
全体の意見や態度の分布は長期間にわたつて安 定する. データの変動が時代効果（成員全体が 受ける時勢による変化)によることがわかれば, 年齢や世代によらず社会の成員全体の意見や態 度がある一定方向に変化する流動的なものであ り, ある時点を境に逆の方向に転換する可能性 がある，あるいは，データの変動がコウホート 効果（時勢や加齢の影響を受けない世代固有の 違い）によることがわかれば, 個々の成員の意 見や態度は変わりにくいが，世代交代によって 社会全体での分布はゆるやかに変化していくと いえる。

\section{1 スポーツ種目のパターン化}

スポーツ種目のパターン（類型）化について は, 従来, 活動の形式, 機能, 技術, 施設など によるのが普通であった。このような類型化に 対して, 多々納ら ${ }^{38)}$ は, 参加者の身体的, 心理的, 社会的特性に着目し, 横断的データからスポー ツ種目を空間に布置し, 特徵付けをおこなって いる. 本稿では, スポーツ参加の変化の構造に 着目し, 年齢・時代・世代（コウホート）効果 の推定值に基づいて, スポーツ種目のパターン （類型）化をおこなう.

\section{3. 研 究 方 法}

\section{1 データ概要}

データは, 財団法人社会経済生産性本部（旧・ 余暇開発センター) によって毎年継続実施さ れてきた「余暇活動に関する調査」（以下「余 暇活動調查」）であり, 1982 年から 2001 年に わたる 20 時点の個票データすべてを使用した. いずれの調査も, 調査時期は 12 月, 調查方法 には訪問留置法が用いられている。標本抽出に は, 多段階無作為抽出法もしくは層化 2 段無作 為抽出法が採用されている. 母集団は 15 歳以 上の成人, 年齢は 5 歳階級幅である. 計画標本 サイズは 1982 年から 1986 年および 2000 年・ 2001 年が 5 万人以上市部 3000 人（200 地点） であり, 1987 年から 1999 年までは 5 万人以上 市部 3,000 人（200 地点）と 5 万人未満市部.
群部 1,000 人（67 地点）の合計 4,000 人（267 地点）である. 全調查年度の有効回収率の平均 は $82 \%$ であった。ただし, 回収率のトレンド では, 調查開始年の 1982 年が $88 \%$ と高く, 以 降徐々に低下して 1988 年が $79 \%$ と最も低くな る. 1990 年以降は $80 \%$ 前半でほほ安定してい る.

「余暇活動調査」には, 余暇活動に関する質 問項目としてスポーツ・レクリエーション・レ ジャー活動を含めて 90 弱の活動項目が存在す る.このうち我々はスポーツ・レクリエーショ ンを中心に, 参加率が比較的高い 25 種目を取 り上げてベイズ型ロジット・コウホートモデル を適用した。 また, 1984 年以降に種目名の変 更がみられたゴルフ（注 5）については，ゴル フコースとゴルフ練習場での活動を別の種目と して, 1984 年以降のデー夕を用いて分析をお こなつた.

なお, 1986 年までと 2000 年・2001年度の 調查対象地域において，母集団が 1987 年から 1999 年までと異なることの影響をみるために, 全調查年について人口 5 万人以上の市部に限定 したデータセットと, 限定しないデータセット を分析対象とし結果を比較した. 両データセッ トの分析結果に本質的な違いが認められなかつ たので, 以下では市部に限定しないデータセッ トの分析結果を採用している.

\section{2 スポーツ参加率}

スポーツ参加率に関しては, 年間 1 回以上当 該種目を実施した場合を「参加」と定義し, 各 調査年度について, 15 歳以上 70 歳未満は 5 歳 階級別に, 70 歳以上は一括してスポーツ参加 率を再集計して, 25 種目, 12 の年齢階級 $\times 20$ の調查時点からなるコウホート表データを作成 した.

\section{3 分析方法}

3.3.1 ベイズ型ロジット・コウホートモテル

社会変化の要因を明らかにするため, 本稿で は, 年齢階級 $\times$ 調查時点別に集計された何らか 
の数量特性データから, 年齢・時代・世代（コ ウホート）効果を分離する中村のベイズ型ロ ジット・コウホートモデルを用いた. 具体的に は, 第 $j$ 調查時点の第 $i$ 年齢階級の参加率を $\pi_{i j}$ とするとき，そのロジット $\eta_{i j}$ を, 次のように 分解するモデルである.

$$
\begin{aligned}
\eta_{i j} \equiv & \log \left[\pi_{i j} /\left(1-\pi_{i j}\right)\right] \\
= & \beta^{G}+\beta_{i}^{A}+\beta_{j}^{P}+\sum_{k=1}^{K} c_{k, i j} \beta_{k}^{c}, \\
& i=1, \ldots, I ; j=1, \ldots, J ; k=1, \ldots, K .
\end{aligned}
$$

ここで, $I$ は年齢階級数, $J$ は調査時点数, $\mathrm{K}$ はコウホート効果の区分数である． $\beta^{G}$ は総平均 効果, $\beta_{i}^{A}$ は年齢効果, $\beta_{j}^{P}$ は時代効果, $\beta_{k}^{c}$ はコウ ホート効果のパラメータであり, 各効果のパラ メー夕の和がゼロになるよう基準化しておく. $c_{k, i j}(\geq 0)$ は, セルのコウホート区分とコウホー 卜効果パラメータの区分の重なりに応じて決ま る重みであり, $\Sigma_{k=1}^{K} c_{k, i j}=1$ を満たすものとする. コウホート効果パラメータの区分は，コウホー ト表に現れる全コウホートの出生年を 5 年幅で 区切って作成した.

コウホート分析における識別問題を克服する ために，3効果のパラメータの漸進的変化の条 件という緩やかな付加条件を取り込み, 赤池の ベイズ型情報量規準 $(\mathrm{ABIC})^{39)}$ 最小化法に基づ いてモデル選択をおこなう． 3 効果を識別する コウホート分析について詳しくは中村 ${ }^{40)}$ - 43) を, コウホート分析を用いたスポーツ参加人口の推 定・予測方法に関しては山本ら ${ }^{8)}$, 中村ら ${ }^{9)}$ 参照.

\subsection{2 スポーツ種目のパターン化}

25 種目の変動パターンを探るため, 3 効果の 各区分を変数

$$
\left(\beta_{1}^{A}, \ldots, \beta_{I}^{A}, \beta_{1}^{P}, \ldots, \beta_{J}^{P}, \beta_{1}^{c}, \ldots, \beta_{K}^{C}\right)
$$

とし, その推定値を変数の值とみなして男女の 種目を別々のものとして計 50 のスポーツ種目 について探索的に分類する階層的クラスター分 析をおこなつた. 各効果の推定值の変動パター ンによってスポーツ種目を分類することにな る. 変数間の距離には平方ユークリッド距離, クラスター間の距離計算には Ward 法を用いた.
なお, 時代効果の推定値を用いてクラスター分 析をおこなう際には，全種目の調査時点をそろ えるため, 1984 年以降の推定值を用いてクラ スター分析をおこなった.

\section{4. 結果}

\section{1 スポーツ参加率の最適モデル選択}

選択対象となるモデルには，3 効果の有無に より，3 効果モデル（APC モデル），2 効果モ デル (AP-, AC-, PC モデル), 単効果モデル (A-, P-, Cモデル), 無効果モデル (G モデル) 98 つが考えられる.ここで, A は年齢 (Age) 効果, P は時代 (Period) 効果, C はコウホート (Cohort) 効果の略号である. Table 1 と Table 2 は, それ ぞれ男性と女性についてのモデル選択表であ り，観察期間が 1982 年から 2001 年までの「余 暇活動調查」から得られる 25 種目について上 位 3 つまでのモデルを示したものである.これ らの表により，スポーツ参加の変動を支配する 要因を概観することができる.

表の左から 1 列目は種目名を示し， 2 列目 には各種目の ABIC 最小の最適モデル（1st model）を，3 列目，5列目にはそれに続くモデ ル (2nd model, 3rd model) を並べている. モ デルの表記には，モデルのもつ 3 効果をその大 きい順番に A (年齢), P (時代), C (コウホート)

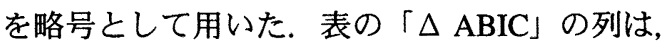
次善以下のモデルと最適モデルとの $\mathrm{ABIC}$ の差 を示す.

ABIC はベイズ型モデルの AIC であるが, $\mathrm{AIC}$ は 1 ～ 2 以上の差があれば有意な差であ るとされる ${ }^{44)}$.そこでここでは, 最適モデルの $\mathrm{ABIC}$ が次善のモデルのそれを 2 以上離してい る種目について「*」を付与した. これを鳥瞰 すると, 男性では 21 種目，女性では 18 種目で 最適モデルが次善のモデルよりもよいと判断で きる. ABIC の差が小さく次善のモデルよりも 最適モデルが必ずしもよいとはいえない場合で も, 3 効果の有無・大きさについてある程度の 判断を下すことができる.

Table 1 と Table 2 の最適モデル（1st model） 
Table 1 Selected models for participation rates in $\mathbf{2 5}$ sports and recreational activities based on the Bayesian logit age-period-cohort analysis (Male)

\begin{tabular}{lccrrr}
\hline Activities & 1st model & 2nd model & \multicolumn{1}{c}{$\Delta$ ABIC } & 3rd model & \multicolumn{1}{c}{$\Delta$ ABIC } \\
\hline Aerobics or Jazz Dancing & C & CP & 1.6981 & CA & 2.3731 \\
Badminton & APC * & AP & 19.9479 & AC & 32.8193 \\
Baseball or Catchball & APC * & AC & 20.1678 & AP & 46.4940 \\
Basketball & AP * & APC & 2.1685 & A & 24.2440 \\
Billiard & PAC * & PA & 62.4529 & PC & 246.4211 \\
Bowling & ACP * & AC & 63.3858 & AP & 100.2166 \\
Bicyling & APC * & AP & 6.0294 & AC & 13.8991 \\
Fishing & ACP * & AC & 34.0672 & AP & 72.8580 \\
Gateball & AP & APC & 0.9145 & AC & 14.9092 \\
Golf (Course) & ACP * & AC & 11.6666 & AP & 90.6743 \\
$\quad$ (Range) & ACP * & AC & 60.3877 & AP & 83.1899 \\
Gymnastics & AP & APC & 0.7588 & AC & 43.5684 \\
Ice skating & APC * & AP & 12.4541 & AC & 17.7802 \\
Jogging or Marathon & ACP * & AC & 13.2065 & AP & 21.8993 \\
Martial Arts & AP & APC & 1.9291 & AC & 2.2832 \\
Skiing & APC * & AP & 50.2249 & AC & 69.1948 \\
Soccer & APC * & AP & 8.2490 & AC & 46.0077 \\
Social Dancing & CAP * & CA & 4.0580 & CP & 6.2924 \\
Softball & ACP * & AC & 45.9936 & AP & 60.5554 \\
Swimming & ACP * & AC & 11.2265 & AP & 86.6858 \\
Table Tennis & APC * & AP & 23.3726 & AC & 53.4757 \\
Tennis & CAP * & CA & 9.5156 & CP & 46.2433 \\
Training & ACP * & AC & 4.1859 & AP & 7.5999 \\
Volleyball & APC * & AP & 3.5640 & AC & 31.0204 \\
Picnic, Hiking, or Walking & ACP * & AC & 47.0139 & AP & 93.8058 \\
\hline
\end{tabular}

により, 25 種目のスポーツのうち, 年齢効果 が男性で 24 種目, 女性で 25 種目で認められた。

これらのうち男性で 21 種目，女性では 22 種目 で選択された効果の順番からわかるように，ス ポーツ参加の変動は年齢効果が最も大きい.

時代効果は男性で 24, 女性で 23 種目で認め られた.これらのうち男女ともビリヤードだけ が, 選択される効果の順番から時代効果が最も 大きいことが認められた. その他の種目の時代 効果は, 2 番目（男性で 12 種目, 女性で 12 種目) もしくは 3 番目（男性で 11 種目, 女性で 10 種 目）に選択されている.

コウホート効果は男女とも 21 種目で認めら れた.これらのうち男性の 3 種目（エアロビク ス・ジャズダンス, 社交ダンス, テニス), 女 性の 2 種目（エアロビクス・ジャズダンス, 社 交ダンス）で，選択される効果の順番からコウ ホート効果が最も大きいことが認められた。 そ
の他の種目のコウホート効果は，2 番目（男性 で 9 種目, 女性で 10 種目）もしくは 3 番目（男 性で 9 種目, 女性で 9 種目）に選択されている.

以上より，スポーツ参加は加齢に伴って変化 することが多く, 社会全体の分布は長期間にわ たつて安定する傾向が大きいといえるが，年齢 や世代によらずある一定方向に変化してある時 点を境に逆の方向に転換する可能性や，個々の 成員のスポーツ参加は変わりにくく世代交代に よって社会全体での分布はゆるやかに変化して いく可能性もみてとれる。但し, Table 1，2の モデル選択表から，スポーツ種目の年齢・時 代・コウホート効果の大きさについては概観す ることはできても, 各効果の変動パターンを概 観することはできない，そこで，次節では，年 齢・時代・コウホート効果の推定值に基づいて スポーツ種目を探索的に分類する階層的クラス ター分析をおこなう. 
Table 2 Selected models for participation rates in 25 sports and recreational activities based on the Bayesian logit age-period-cohort analysis (Female)

\begin{tabular}{lccrrr}
\hline Activities & 1st model & 2nd model & \multicolumn{1}{c}{$\Delta$ ABIC } & 3rd model & \multicolumn{1}{c}{$\Delta$ ABIC } \\
\hline Aerobics or Jazz Dancing & CPA * & CP & 5.6830 & CA & 18.0559 \\
Badminton & ACP * & AC & 6.7368 & AP & 10.3932 \\
Baseball or Catchball & AP & APC & 1.1014 & AC & 14.5290 \\
Basketball & APC * & AC & 4.9712 & A & 12.5841 \\
Billiard & PAC * & PA & 15.9858 & PC & 141.4561 \\
Bowling & ACP * & AC & 65.3697 & AP & 107.7020 \\
Bicyling & ACP * & AC & 3.3886 & AP & 24.2362 \\
Fishing & APC * & AP & 11.6496 & AC & 54.5251 \\
Gateball & APC & AP & 0.0691 & AC & 5.0195 \\
Golf (Course) & AC & APC & 1.1910 & AP & 31.0489 \\
$\quad$ (Range) & APC * & AP & 36.3919 & AC & 71.5067 \\
Gymnastics & APC * & AP & 21.2446 & AC & 22.9645 \\
Ice skating & APC * & AP & 29.4650 & AC & 34.9545 \\
Jogging or Marathon & ACP * & AC & 14.7611 & AP & 105.3190 \\
Martial Arts & A & AC & 1.8353 & AP & 1.8891 \\
Skiing & APC * & AP & 54.5196 & AC & 54.5550 \\
Soccer & AP & APC & 1.1538 & AC & 11.1917 \\
Social Dancing & CAP & CA & 0.8148 & CP & 11.9966 \\
Softball & ACP * & AC & 21.1339 & AP & 24.8652 \\
Swimming & ACP * & AC & 12.3679 & AP & 178.0461 \\
Table Tennis & APC * & AP & 2.1124 & AC & 28.1975 \\
Tennis & ACP * & AC & 11.2695 & AP & 101.4383 \\
Training & AP & APC & 1.9671 & AC & 13.7035 \\
Volleyball & ACP * & AC & 8.2114 & AP & 22.4420 \\
Picnic, Hiking, or Walking & ACP * & AC & 40.7293 & AP & 150.2771 \\
\hline
\end{tabular}

\section{2 スポーツ参加の 3 効果の変動パターン}

各クラスターに所属するスポーツを男女別に 表にしたのがそれぞれ Table 3 と Table 4 であ る. 対象となったスポーツは各効果の変動パ ターンが類似している種目同士で順次グルーピ ングされるが, クラスター凝集経過工程表の係 数の変化量と, 各クラスターの説明のしやすさ から, 年齢効果の変動パターンを 4 つ, 時代効 果は 5 つ, コウホート効果は 6 つのクラスター に分類した. なお, 各種目の変動パターンをみ る場合は, 年齢効果, 時代効果, コウホート効 果の順で, 男性のバレーボールは 1-1-3，バス ケットボールは 1-3-3，スキーは 2-4-5 という ような変動パターンに対応したクラスターの特 徵を持つことになる.

Fig. 1，2，3は，それぞれ年齢，時代，コウ ホート効果について, Table 3, 4 で得られたク ラスター平均值をグラフ化したものであり，各
効果における個々のクラスターの変動パターン を見ることができる. 図では 0 の基準線のまわ りに点がプロットされ，点が上側にあるほど参 加率を高めることを意味することになる．各効 果のクラスターは, 開始時点で図の上側に位置 するクラスターから順次, 年齢効果の場合は Age $1 \sim$ Age 4, 時代効果の場合は Period 1 Period 5, コウホート効果の場合は Cohort 1 〜 Cohort 6 と名付けることとした. なお，各効果 の推定值は参加率のロジット変換後の值に対す るものであり，值が大きいほど参加率を高くす るが，以下での各クラスターにおける増減の記 述は参加率そのものの大きさとは必ずしも対応 しないことに注意する（注 6 ）。

\subsection{1 年齢効果の変動パターンのクラスター}

Table 3，4，およびFig. 1 からわかる年齢効 果のクラスターの特徵を以下に示す.

Age 1 クラスターは, 若い年齢層の参加が 4 
Table 3 Changing pattern of sports participation by age, period, and cohort effects (Male)

\begin{tabular}{|c|c|c|c|}
\hline Activities & Age effect & Period effect & Cohort effect \\
\hline Volleyball & Age 1 & Period 1 & Cohort 3 \\
\hline Basketball & Age 1 & Period 3 & Cohort 3 \\
\hline Soccer & Age 1 & Period 3 & Cohort 3 \\
\hline Badminton & Age 2 & Period 1 & Cohort 4 \\
\hline Baseball or Catchball & Age 2 & Period 1 & Cohort 4 \\
\hline Softball & Age 2 & Period 1 & Cohort 4 \\
\hline Ice skating & Age 2 & Period 1 & Cohort 5 \\
\hline Tennis & Age 2 & Period 1 & Cohort 5 \\
\hline Jogging or Marathon & Age 2 & Period 2 & Cohort 3 \\
\hline Martial Arts & Age 2 & Period 2 & Cohort 3 \\
\hline Table Tennis & Age 2 & Period 2 & Cohort 4 \\
\hline Swimming & Age 2 & Period 2 & Cohort 5 \\
\hline Training & Age 2 & Period 3 & Cohort 5 \\
\hline Bowling & Age 2 & Period 4 & Cohort 5 \\
\hline Skiing & Age 2 & Period 4 & Cohort 5 \\
\hline Billiard & Age 2 & Period 5 & Cohort 1 \\
\hline Social Dancing & Age 3 & Period 1 & Cohort 2 \\
\hline Gymnastics & Age 3 & Period 1 & Cohort 3 \\
\hline Bicyling & Age 3 & Period 2 & Cohort 3 \\
\hline Fishing & Age 3 & Period 2 & Cohort 3 \\
\hline Golf (Course) & Age 3 & Period 2 & Cohort 4 \\
\hline (Range) & Age 3 & Period 2 & Cohort 4 \\
\hline Picnic, Hiking, or Walking & Age 3 & Period 2 & Cohort 4 \\
\hline Aerobics or Jazz Dancing & Age 3 & Period 2 & Cohort 5 \\
\hline Gateball & Age 4 & Period 1 & Cohort 3 \\
\hline
\end{tabular}

Table 4 Changing pattern of sports participation by age, period, and cohort effects (Female)

\begin{tabular}{|c|c|c|c|}
\hline Activities & Age effect & Period effect & Cohort effect \\
\hline Softball & Age 1 & Period 1 & Cohort 4 \\
\hline Ice skating & Age 1 & Period 1 & Cohort 5 \\
\hline Badminton & Age 1 & Period 2 & Cohort 3 \\
\hline Baseball or Catchball & Age 1 & Period 2 & Cohort 3 \\
\hline Volleyball & Age 1 & Period 2 & Cohort 4 \\
\hline Tennis & Age 1 & Period 2 & Cohort 5 \\
\hline Basketball & Age 1 & Period 3 & Cohort 3 \\
\hline Soccer & Age 1 & Pexiod 4 & Cohort 3 \\
\hline Social Dancing & Age 2 & Period 2 & Cohort 2 \\
\hline Table Tennis & Age 2 & Period 2 & Cohort 3 \\
\hline Jogging or Marathon & Age 2 & Period 2 & Cohort 4 \\
\hline Bicyling & Age 2 & Period 2 & Cohort 5 \\
\hline Swimming & Age 2 & Period 2 & Cohort 6 \\
\hline Fishing & Age 2 & Period 3 & Cohort 1 \\
\hline Martial Arts & Age 2 & Period 3 & Cohort 3 \\
\hline Training & Age 2 & Period 3 & Cohort 3 \\
\hline Bowling & Age 2 & Period 4 & Cohort 5 \\
\hline Skiing & Age 2 & Period 4 & Cohort 5 \\
\hline Billiard & Age 2 & Period 5 & Cohort 1 \\
\hline Gymnastics & Age 3 & Period 2 & Cohort 3 \\
\hline Picnic, Hiking, or Walking & Age 3 & Period 2 & Cohort 5 \\
\hline Aerobics or Jazz Dancing & Age 3 & Period 2 & Cohort 6 \\
\hline Golf (Course) & Age 3 & Period 2 & Cohort 6 \\
\hline (Range) & Age 3 & Period 4 & Cohort 6 \\
\hline Gateball & Age 4 & Period 1 & Cohort 3 \\
\hline
\end{tabular}




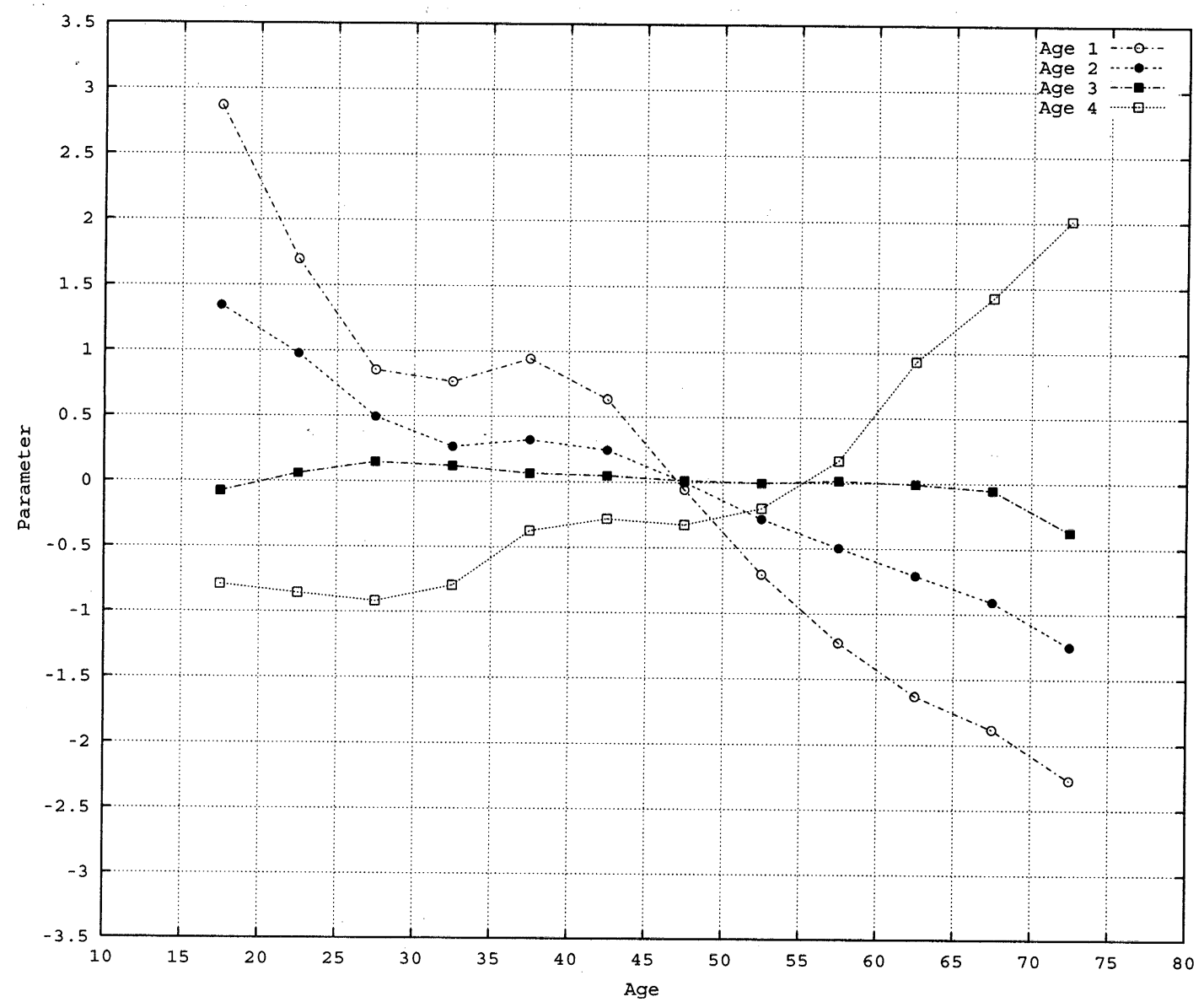

Fig. 1 Mean values of the estimates over activities belonging to the clusters constructed according to age effects

つのクラスター中最も高く, 30 歳台にプラトー やリバウンドが見られるが，その後加齢にとも ない 40 歳台から急激に参加率低下がみられる クラスターである. 男女に共通してバスケット ボール, サッカー, バレーボールが, 女性だけ にバドミントン, ソフトボール, テニスなどが 含まれる. Age 1 クラスターに属するスポーツ は, 身体的運動強度が高く, 全般的に集団スポー ツである傾向が強い.

Age 2 クラスターは, 若い年齢層では参加率 が中程度で, 30 歳台前半から 40 歳台前半にか けて一時持ち直したりプラトーを形成するが, 加齢とともに参加がゆるやかに低下するグルー プである. 男性で 13 種目, 女性で 11 種目と多 くのスポーツがこのクラスターに含まれる.こ
の Age 2 クラスターに属するスポーツは, 身体 的運動強度が比較的高い点では Age 1 クラス ターと同様であるが, 男性の野球・ソフトボー ルを除けば, 全般的に対人スポーツである傾向 が強い.

Age 3 クラスターは, 加齢に伴う増加や減少 が小さく安定している，もしくは，若い年齢層 ではそれほど参加が高くなく，中年もしくは高 齢者にボリュームがあるクラスターである，男 女に共通して, エアロビクス, ゴルフ, 体操, ウォーキングなどが属しており, フィットネ ス・健康関連の種目が多く, レクリエーション 的である傾向も強い. また, 人数を必要としな いスポーツであるのは Age 2 クラスター同様で ある。 


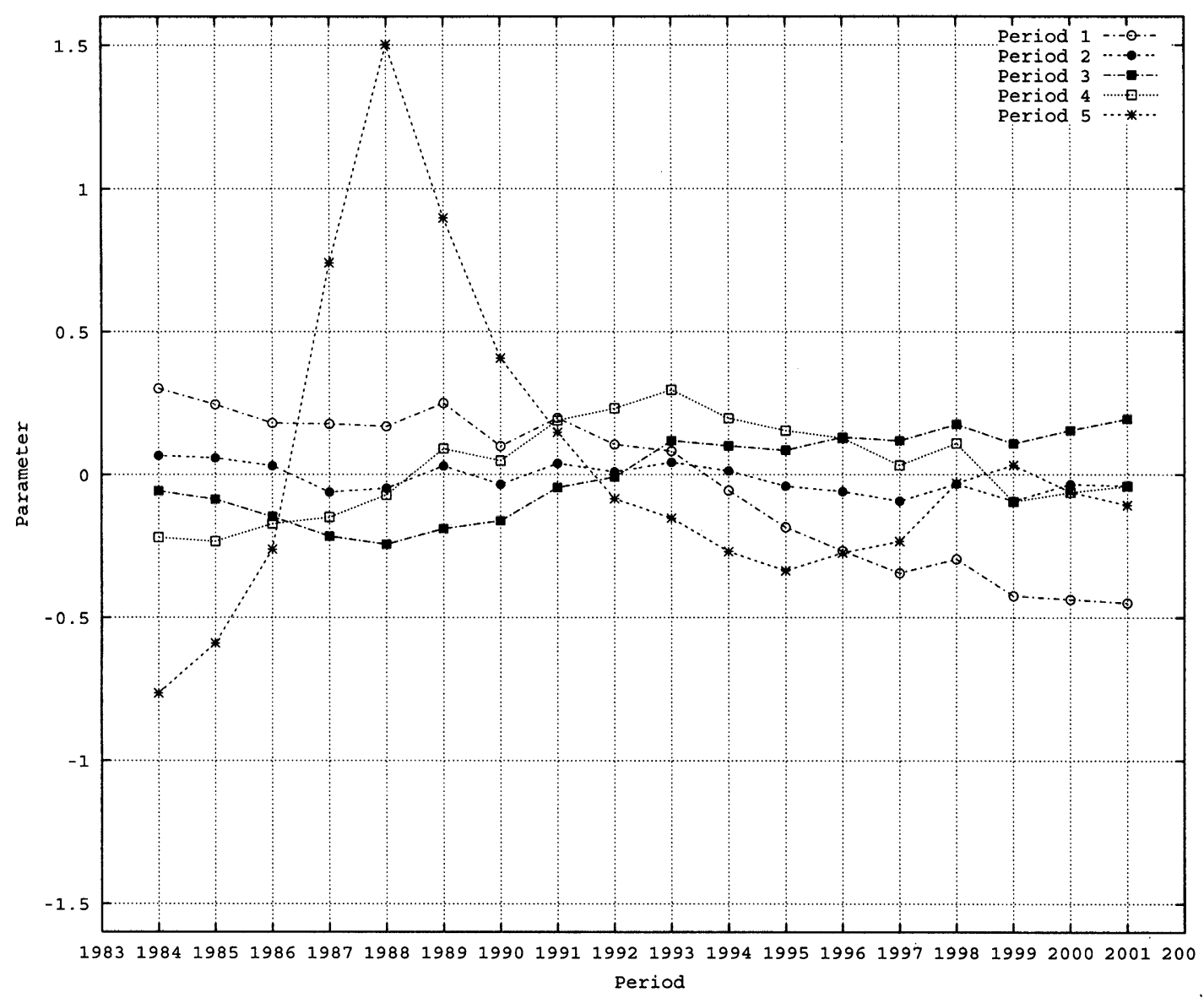

Fig. 2 Mean values of the estimates over activities belonging to the clusters constructed according to period effects

Age 4 クラスターは, 若い年齢層の参加が低 く, 加齢にともない参加率の増加がみられる種 目であり，他の種目とは全く異質の種目といえ る. 該当するのはゲートボールである.

\subsection{2 時代効果の変動パターンのクラスター}

Table 3，4, Fig. 2 からわかる時代効果のク ラスターの特徽を以下に示す.

Period 1 クラスターは, 男女とも減少傾向が 大きいクラスターであり, 1984 年時点では最 も参加が高かったが, 1990 年代に入ると減少 し続け, 2000 年代前半には最も参加が低いク ラスターとなっている. 男性では野球, テニ ス，バレーボールなど 9 種目が，女性ではゲー トボール, ソフトボール, アイススケートなど の 3 種目が該当している.
Period 2 クラスターは, 時代効果が小さく安 定しているか，もしくは数年間隔で増減を繰り 返すが全体的には安定しているクラスターであ る. 男性で 10 種目, 女性では 13 種目と多くの スポーツがこのクラスターに分類され，エアロ ビクス・ジャズダンス, 自転車, ジョギング, 水泳・ウォーキング, ゴルフコースなどのフィッ トネス・健康関連の種目が男女に共通して, 女 性だけにバドミントン, 体操, 社交ダンス, テ ニス, バレーボールが含まれる.

Period 3 クラスターは, 1980 年代後半から, 増加傾向を維持するクラスターであり, バブ ル期以降も微増傾向を示している．バスケット ボール, サッカー, トレーニングが男女に共通 し，女性だけに釣り，武道が含まれる。 


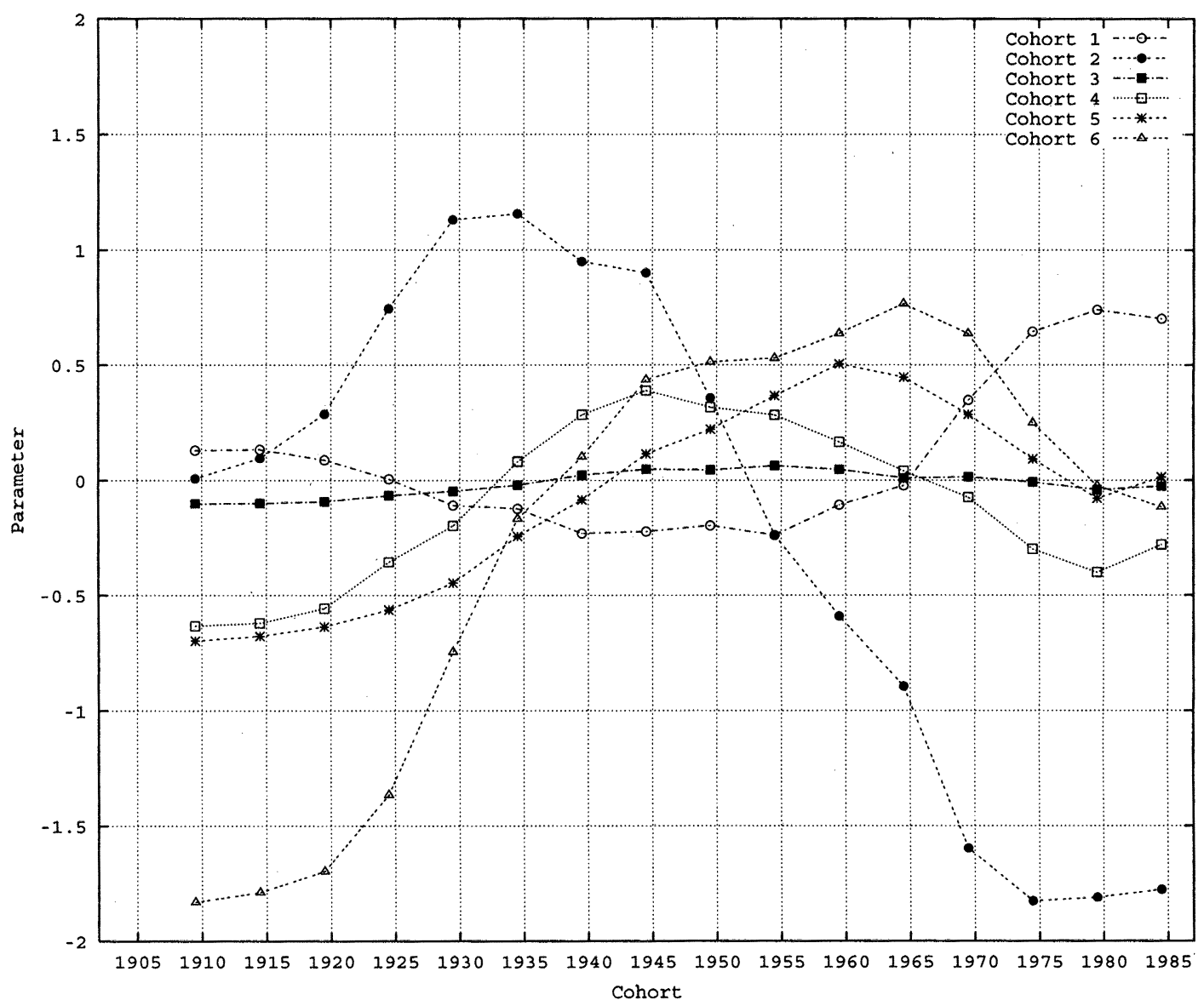

Fig. 3 Mean values of the estimates over activities belonging to the clusters constructed according to cohort effects

Period 4 クラスターは, 1984 年時点からバブ ル期の 1993 年にかけて参加増がみられ, 以降 は微減傾向にあるクラスターである. バブル期 にあわせて山が形成されている，ボウリング, スキーが男女に共通して，女性だけにゴルフ練 習場, サッカーが含まれる.

Period 5 クラスターはビリヤードが該当し, 1984 年から 1988 年にかけて類を見ないほど 急激に参加率が上昇し，一転 1996 年まで急激 に参加率は減少している. その後の動向では, 1995 年以降微増傾向にある. これほど時代効 果が大きいスポーツは過去 20 年間ではみられ ない.

\subsection{3 コウホート効果の変動パターンのクラ スター}

Table 3, 4, Fig. 3 からわかるコウホート効 果のクラスターの特徵を以下に示す.

Cohort 1 クラスターは, 古い世代とより新 しい世代の参加が高く, 団塊の世代（1947 1949 年生まれ）を含んだ前後の 1937-41 年, 1952-56 年生まれの世代が低い. 男女に共通し てビリヤード，女性だけに釣りが含まれる.

Cohort 2 クラスターは, 1927-31 年から 1942-46 年生まれの戦前生まれ世代で高く, 男 女ともその後の新しい世代では低くなってい る. 社交ダンスが該当している.

Cohort 3 クラスターは，男女とも 9 種目のス ポーツが属すクラスターであり, その特徵とし 
ては，コウホート効果が無いか, 緩やかで小さ く，世代間での参加に大きな差が見られないク ラスターである. 男女に共通して, バスケット ボール, ゲートボール, 体操, 武道, サッカー などが該当している.

Cohort 4 クラスターは, 1942-46 年生まれの 世代を中心に山が形成されているクラスターで ある. 男性では, 野球, ゴルフ, ウォーキング などが, 女性ではジョギング, ソフトボール, バレーボールが該当している.

Cohort 5 クラスターは, ポスト団塊の世代の 1957-61 年生まれの世代を中心とした山が形成 されている，男女に共通して，ボウリング，ア イススケート, スキー, テニスなどが認められ る. 男性だけにエアロビクス, 水泳, トレーニ ングが, 女性だけに自転車, ウォーキングが含 まれる。

Cohort 6 クラスターは, 団塊の世代から 1962-66 年生まれ前後の世代にボリュームのあ るクラスターであり, より新しい世代の参加は 低くなっている. 女性のエアロビクス, ゴルフ, 水泳が該当している.

\section{5. 考察}

\section{1 年路効果}

スポーツ参加の変動は,「加齢にともないス ポーツ参加から離脱する傾向が高い」 ${ }^{10)}$ と考え られてきた. 本稿の結果からも, 年㱓に依存し た変化が強く, 社会全体のスポーツ参加の分布 は長期間にわたって安定する傾向が高いことが 指摘できる. しかし，これらの結果は加齢にと もなう離脱というパターンだけでは説明がつか ないものであった.

Age 1, Age 2 のクラスターは, いずれのク ラスターも若い年齢層の参加が高く, 30 歳台 前半から 40 歳台前半にかけて一時リバウンド やプラトーを形成しながら, 加齢とともに参加 が低下している.「加齢にともない，スポーツ 参加から離れていく」という離脱説を支持する 傾向を示し，25 種目のうち男性で 16 種目, 女 性で 19 種目のスポーツが該当している. 具体
的には, 加齢に伴う年齢効果の減少が顕著で ある Age 1 クラスターはバスケットボール, バ レーボール, サッカーなどの集団スポーツであ る傾向が強く, 加齢に伴う減少が若干緩やかに なる Age 2 クラスターになると, テニス, バド ミントンなどの対人スポーツやジョギング, 水 泳, トレーニング，スキーなどの個人スポーツ である傾向が強くなる.

他方, Age 3, Age 4 クラスターは, 若い年 齢層ではそれほど参加が高くなく，むしろ中高 年もしくは高齢者にボリュームがあるか, 中高 年の参加率低下が緩やかであるパターンであ り, 離脱説を否定する傾向を示している，具体 的には，加齢にかかわらず年齢効果が安定して いる Age 3 クラスターでは, 体操, 自転車, ゴ ルフ, ウォーキング, エアロビクスなどのフィッ トネス・健康関連のスポーツ・レクリエーショ ン種目が多くなる傾向が高くなっている.

これらの離脱説を肯定するスポーツと, 否定 するスポーツがある結果は, 同一時点の年齢間 比較から，「年齢によってスポーツ活動を開始・ 中止・代替・継続する割合に特定の傾向があ る」としてきた Jackson and Dunn ${ }^{18)} ゃ$ Searle and Brayley ${ }^{19)}$, Iso-Ahola ${ }^{20)}$ の示唆と符合する傾向 であるといえ，人々は加齢に応じた体力の低 下, 一緒にプレイする友人の存在, 健康維持の 意識などの要因からスポーツを開始・中止・代 替・継続していることが, 継続調查データのコ ウホート分析からも認められる. また, Age 1, Age 2 にみられる, 30 代前半から 40 代前半に かけて参加が高まるリバウンドやプラトーにつ いては，近年の平均初婚年齢が晚婚化（男性 29.4 歳, 女性 27.6 歳: 2001 年 ${ }^{45)}$ していること, 第 1 子平均出生年齢も高齢化 (29.8 歳:2000 年) していることもあわせて考えると, 子供といつ しょにおこなったために，これらの年齢層でリ バウンドしたり，プラトーが形成されているの であろう ${ }^{37)}$.

最後に, 加齢の要因を通じたスポーツ人口そ のものの将来動向について考える. 年齢効果が 大きいことは社会にとっては基本的に安定要因 
であるが, 人口規模の変動を通じてスポーツ人 口の変動に影響をもたらす．スポーツ人口の変 動には各スポーツの時代効果やコウホート効果 の動向の方が大きく寄与するものの, 以下では, 加㛔以外の要因の影響が小さいものと想定して 話をすすめる. 加齢に伴い参加が低下する傾向 と少子高歯化の影響から, Age 1, Age 2 クラ スターのスポーツ人口は, 減少していく可能性 が高いといえる. 一方, Age 3, Age 4 クラスター のスポーツ人口は, 20 歳代から中高年齢層ま でボリュームがあるため, 少子高齢化が進行し てもしばらくはそれほど減少しない可能性が高 いといえる.

\section{2 時代効果}

スポーツ参加の変動は, 景気や流行などの時 勢の影響を受けると考えられてきた. しかし， 継続調査データの不足やコウホートデータに含 まれる識別問題のため, スポーツ参加の変動か ら時勢要因の影響を取り出して景気や流行との 関連を分析した研究は未だない. 本稿の結果に より, スポーツ参加の変動は, 年齢や世代によ らずある一定方向に変化する流動的なものであ り, ある時点を境に逆の方向に転換する可能性 が高いことが認められた.ただし，時勢の要因 がすべてのスポーツ参加の変動に影響を及ぼす わけではなかった.

Period 1 クラスターは, 時代効果の減少傾向 が大きく, 1984 年からバブル期までは微減, バブル期以降に減少傾向が増している. 単年度 であれば増加することもあるが， 2 年連続して の増加は見られず，社会全体におよぶ時勢要因 から参加が減少し続けている. これらのクラス 夕ーに属する個々のスポーツは男性のスポーツ 種目が多く, 具体的にはバレーボール, バドミ ントン, 野球, テニスなどの競技スポーツと社 交ダンス, アイススケート, ゲートボールなど が該当している.これらのスポーツ業界にとつ てはかなり深刻な事態となっている. なんらか の対策を講ずる必要があるだろう.

Period 2 クラスターは, 時代効果が小さく安
定している．男性では 10 活動，女性では 13 活 動が該当している。このクラスターの特徴とし て, 男女に共通してジョギング, 水泳, 自転車, ウォーキング, エアロビクスなどのフィットネ ス・健康関連の種目が中心となっている，女性 だけにレクリエーション的な種目も含まれてい るが, 基本的にフィットネス・健康関連のスポー ツ参加が景気や流行に左右されにくいことが伺 える.さらに男性だけに見られる傾向であるが, Period 2クラスターに含まれるスポーツ種目は, Age 3 クラスターと共通する種目が多いのは興 味深い. 男性のフィットネス・健康関連の種目 は，若い年齢層から高齢者まで広く参加がある とともに，流行や景気などの時勢の影響を受け にくく安定した参加があることを示している.

Period 3 クラスターは, バスケットボール, サッカー, トレーニングが男女に共通して，女 性だけに釣り，武道などが含まれている，そ の特徵は, 80 年代後半から微增傾向を維持し, バブル崩壊以降も若干の微増傾向を示してい る.これらのクラスターに含まれる個々のス ポーツに，どのような時勢の要因が働いていた かは, 今後個々の種目毎の結果を詳細に検証し ていきたいが, 大まかに考えると, 参加の増加 傾向が最も顕著であった 1988 年から 1993 年ま での背景には，サッカーではアジアカップ優勝 (1989 年), ドーハの悲劇・Jリーグ発足（1993 年), 日韓ワールドカップ開催など，バスケッ トボールでは「スラムダンク」の連載（1990 〜 96 年: 週刊少年ジャンプ）およびテレビ放 映（1993～96 年: テレビ朝日）, トレーニン グでは,「Tarzan」などのフィットネス・健康 に関する雑誌の創刊（1987 年）や,フィット ネスクラブの新設ラッシュ（1987 年〜 90 年） など，一般的に参加増に影響を与えたとされて いる通説と符合していることが確認できる.た だし，これらの要因が与えた影響は微少である ことは興味深い.

Period 4 クラスターは, 男性でボウリング, スキ一, 女性ではサッカー, ボウリング, スキー, ゴルフ練習場が該当し,バブル期に参加増加を, 
バブル崩壊以降には参加減少を示している，該 当するスポーツに共通する特徵は, 参加費用が 高い, 景気循環・家計所得などの外的要因の変 動と相関が高いようである.

Period 5 クラスターは, 急激な参加増加と減 少がみられ，ビリヤードが該当している. 80 年代後半のバブル期には，プールバーなどを 中心としたビリヤードブームがおこり，全世代 の人々がビリヤードに興じたことで，大幅な参 加増がみられた。これほどの時勢の影響は過去 20 年間では見あたらない. 70 年代前半のボウ リングブーム同様の急激な増加と減少が認めら れる。一過性の短い期間ブームであった点も共 通した特徵となっている. 次に, 時勢の要因か らみたスポーツ全体の特徴を鳥瞰する.

先行研究では, 加齢, 時勢, 世代の 3 つの要 因が混交したままのデータに基づいて，スポー ツ参加の変動は, 1 人あたり所得 (Per-capita income $)^{25)}$, 景気循環 (Economic Cycle) ${ }^{26)}$, スポー ツ施設・サービスの供給量 ${ }^{46}$, 消費者ニーズの 多様化·若年層のスポーツ離れの進行 ${ }^{24) 47)}$ など, 外的要因と結びついていると示唆されてきた. 本稿の結果からも，外的要因などの時勢の影響 を受けることが示されたが，モデル選択表の効 果の順番から, 時代効果が最大なのはビリヤー ドのみであった．大半の種目では時勢の要因よ りも加龄や世代の要因の方が支配的であった. 今後は, 個々のスポーツ毎に, 年齢効果と家計 所得, 景気の指標などの関連性を詳細に検証し ていきたい.

最後に, 時勢の要因を通じたスポーツ人口そ のものの将来動向について考える. 時勢の変化 は社会全体に及ぶ流動的なものであり，将来の スポーツ人口の変動に大きな影響を与える，以 下では, 時勢以外の要因の影響が小さいものと 想定して話をすすめる.

Period 1 クラスターの場合は, 時代効果があ る時点から転換しないかきり, さらに減少して いく可能性が高いといえる. Period 2 クラスター の場合は, 時代効果が比較的安定していること から, 急激な増減はない可能性が高いといえる.
Period 3 クラスターの場合は, 時代効果がある 時点から転換しない限りは, 比較的安定して增 加していく可能性が高い. 他のクラスターの 傾向とは逆のトレンドとなっていることから, Period 3 クラスターのスポーツ人口はより増加 していく可能性が高いといえる. Period 4 クラ スターの場合は, 時代効果がバブル以降のトレ ンドで推移してゆくならば, スポーツ人口はさ らに減少していくであろう. Period 5クラスター の場合は, 90 年代後半からのトレンドが維持 されるようであれば，スポーツ人口は長期低迷 する可能性が高いといえる. 但し, 我々が先に 示したように, スポーツ人口の予測值は, 年齢 効果, 時代効果, コウホート効果, 人口規模の 変動の 4 つのあり方すべてに依存する. 特に時 代効果とコウホート効果のシナリオは予測值を 大きく左右する. 実際のスポーツ人口の推定 · 予測については山本ら ${ }^{8)}$ を参照されたい.

\section{3 コウホート効果}

スポーツ参加に対する世代の要因の影響を取 り上げた研究は, ある時点の高齢者層などに過 去に遡って質問し，同一世代（コウホート）の 参加パターンを分析する研究 ${ }^{29)}$-33) か, 継続調 査データを用い, 年齢階級 $\times$ 調查時点別の集計 データを分析する研究 ${ }^{34)-37) て ゙ あ っ た . ~ い す ゙ れ ~}$ の研究においても, スポーツ参加の変動から世 代要因の影響を取り出した研究は未だない。本 稿の結果により, スポーツ参加の変動は, 個々 の成員のスポーツ参加は変わりにくいが, 世代 交代によって社会全体での分布はゆるやかに変 化していくことが認められた. しかし，すべて のスポーツ参加に同様の世代差が存在するわけ ではない. そのパターンは6つに分けられた.

Cohort 1 クラスターは, 男女に共通してビリ ヤード，女性だけで釣りが該当しているが，団 塊の世代（1947〜 1949 年生まれ）を含んだ前 後の 1937-41 年, 1952-56 年生まれの世代が低 く, 新しい世代である 1972-76 年生まれから, 1982-86 年生まれのコウホートの参加が非常に 高い. 時代効果と併せて考えると，1988 年の 
ビリヤードブーム時に 16 歳前後であった新し い世代に，時勢の影響が定着しているようであ る.

Cohort 2 クラスターは，選択される効果の順 番からコウホート効果が最も大きいと認めら れた社交ダンスが該当している。 その特徵は 1927-31 年から 1942-46 年生まれの戦前生まれ 世代の参加が高く，その後の新しい世代になれ ばなるほど参加が低くなっている．現在の 70 代のシルバー世代からは絶大な支持を受けてお り，1927-31 年から 1942-46 年生まれ世代では 最も参加が高いスポーツとなっている.

Cohort 3 クラスターは，バスケットボール， ゲートボール, 体操, 武道, サッカーなどがあ たり，コウホート効果が無いか，緩やかで小さ く，世代間での参加に大きな差が見られないク ラスターである.

Cohort 4 クラスターは, 1942-46 年生まれの 世代を中心に山が形成されているクラスターで あり，男性では，野球，ゴルフ，ウォーキング などが，女性ではジョギング，ソフトボール， バレーボールが該当している. 1942-46 年生ま れの以降の世代は，参加が減少していく傾向を 示している.

Cohort 5 クラスターは，男女に共通して，ボ ウリング, アイススケート, スキー, テニスな どが，男性だけでエアロビクス，水泳，トレー ニング，女性だけで自転車，ウォーキングが該 当し，ポスト団塊の世代の 1957-61 年生まれの 世代を中心とした山が形成されている．このク ラスターに属しているスポーツは戦後の一時期 にブームが形成されたものが多いのが興味深 い. 例えば, 戦後のスポーツブームを紐解くと, 50 年代から 60 年代にかけてのスキーブーム, 70 年代前半のボウリングブーム, 70 年代から 80 年代中頃までのテニスブーム, 80 年代前後 のジョギングブーム, 80 年代前半のエアロビ クスブーム, スイミングスクールブーム, など である. ボリュームがある 1957-61 年生まれの 世代はこれらのすべてのブームをライフコース を通じ主役として経験してきているといえるだ
ろう.

Cohort 6 クラスターは，女性のエアロビク ス, ゴルフ, 水泳が該当し，団塊の世代から 1962-66 年生まれ前後の世代にボリュームがあ る. その後の新しい世代の参加は低い. 次に, 世代の要因からみたスポーツ全体の特徵を鳥瞰 する。

先行研究では, スポーツ参加の変動には, 世代 固有の特徵があることが示唆されてきたが ${ }^{34335337), ~}$ 本稿の結果から, コウホート効果が現れるスポー ツは, 若い頃に身につけた行動パターンやライフ スタイルは, 後のライフステージまで継続すると する老年社会学の継続説を支持する傾向が認め られた. 各世代はそれぞれスポーツ参加に固有の 特徽を持っており, 辿ってきたライフコースで経 験したイベントを通じて（時勢の影響が特定の世 代に定着した結果)，コウホート効果が現れてい ると考えられる. 今後, 同じ時勢の影響が時代効 果とコウホート効果にどのように現れるかについ てはさらなる検証が必要である.

最後に，世代差の要因を通じたスポーツ人口 そのものの将来動向について考える. コウホー 卜効果が大きい種目は，世代交代を通じて社会 全体の参加率が変化することになる. 以下では, 世代差以外の要因の影響が小さいものと想定し て話をすすめる.

Cohort 1 クラスターの場合は, 最も新しい 1982-86 年生まれのコウホート以降の参加が維 持，もしくは高まるようであれば，世代交代を 通じて緩やかに増加していく可能性が高いとい える. Cohort 2 クラスターの場合は, より若い 世代の参加が非常に低く, 参加が高い古い世代 が高齢であることから，急激に減少していく可 能性が高い. Cohort 3 クラスターの場合は, コ ウホート効果が小さいため, 年齢効果を通じた 人口構成の変化の影響と時代要因が今後のス ポーツ人口を規定することになる. Cohort 4 ク ラスターの場合は, より新しい世代の参加が高 まらない限り, 緩やかに減少する可能性が高い といえる. Cohort 5 クラスターの場合は, より 新しい世代の参加が高まるか, 低まるかによっ 
てスポーツ人ロの今後の増減は正反対となる. Cohort 6 クラスターの場合は, 新しい世代の参 加が高まらなければ，緩やかに減少していく可 能性が高いといえる.

\section{6. まと め}

従来, スポーツ参加の変動は, 「年齢に依存 する影響が強く加齢にともないスポーツ参加か ら離脱する傾向がつよい」，「年歯によってス ポーツ活動を開始・中止・代替・継続する割合 に特定の傾向がある」,「加齢の影響だけでなく, 時勢の影響や世代の影響がある」と示唆されて きた. しかし，これらの各研究が用いたデー夕 には，3つの加齢・時勢・世代差の要因が混交 しているにもかかわらず，各要因の影響を分離 せずにそのまま解釈したものであり，どの要因 がスポーツ参加の変動にどの程度影響している かは不定であった。

本稿では, 20 時点（1982 年〜 2001 年）の継 続調査デー夕に基づいて，ベイズ型ロジット・ コウホートモデルから年齢・時代・コウホート 効果を分離し, 得られた 3 効果の推定値により スポーツ参加の変動パターンを分類することを 目的とした．各クラスターの変動が 3 要因のい ずれによってどのように変化しているか, また 今後の動向についても報告した.

Table 1, 2 の結果によると, 過去 20 年のスポー ツ参加の変動は, 選択される効果の順序から年 齢効果（各成員の加齢による変化）が最大であ るが，年齢効果に続き時代効果・コウホート効 果も選択された. 得られた推定值に基づいてス ポーツ種目を分類した Table 3, 4, 各クラスター の平均值をグラフ化した Fig. 1，2，3 のように, 年齢効果は 4 つ, 時代効果は 5 つ, コウホート 効果は 6 つにパターン化された.

各効果のクラスターにより，年齢効果では加 齢に伴い参加から離脱する傾向だけでなく，離 脱説を否定する傾向が，時代効果では家計や景 気循環の影響を受ける種目や，コミックや TV アニメーションと関連している可能性が，時勢 の影響が特定の世代に定着したと考えられるコ
ウホート効果では，各世代が各々のライフコー スで身につけた行動パターンやライフスタイル が, 後のライフステージまで継続する傾向が認 められた。

今後は，時代効果と家計所得や景気の指標な ぞの経年データの関連性, 時勢要因が一過性の ものであるか, 特定の世代に定着するのか検証 することで，国や地方自治体のスポーツ政策, 公共スポーツ施設の設置計画およびサービスの 効率化，スポーツ・レジャーに関わる企業戦略 などに, 有益な示唆を与えられれば幸いである。

\section{謝辞}

本研究は我が国の余层活動に関する動向を記 録してきた貴重な史料である，財団法人「社会 経済生産性本部」(旧：財団法人「余暇開発セン ター」）による「余层活動に関する調查」データ を使用した. 余层活動調査データの利用にあたつ ては柳田尚也氏にご尽力頂きました.ここに記し て心より感謝いたします．また，本研究の一部は 統計数理研究所共同研究 (12-共研-2044，13-共研 -2053，14-共研-2056，15-共研-2044，16-共研-2050, 17-共研-2061）の援助を受けています.

\section{（注 1) スポーツ人口}

スポーツ延ベ参加人数 (total number of participants) は，延べ利用者数やスポーツ実施延べ人口などと も呼ばれ，頻度を考慮した参加率と各年齢階級の 人口規模の積から求められる。 また, スポーツ（参 加）人口（number of participants）は，スポーツ参 加人数とも呼ばれ，当該スポーツ活動に年 1 回以 上参加した人数であり，頻度を考慮しない参加率 と各年齢階級別の人口規模の積から求められる.

(注 2 ) コウホート

コウホート (cohort) とは，語源的にはローマ時 代の軍団の単位を表すが，主に出生をほほ同時期 にする人口集団を指す.

（注 $3 ） 1$ 人当たり所得

経済全体の所得を全人口数で割った值. 経済成 長を量的に捉える基本指標の 1 つであり，国民の 生活水準を捉える指標でもある ${ }^{49)}$.

\section{（注 4) 識別問題}

年齢・時代・コウホート効果の間には, 数学的 
に 1 次従属の関係が存在するため, 何らかの制約 条件がなければ一義に推定できないという識別問 題が存在する.

（注 5 ） ゴルフコースとゴルフ練習場

1982，83 年調査では「ゴルフ」として質問され ていたのが, 1984 年以降の調査では「ゴルフコース」 と「ゴルフ練習場」として別の質問項目に分かれた.

（注 6 ）ロジット変換後の推定值

各効果の推定值は参加率のロジット変換後の值 に対するものであり，例えば，ある効果の 0.5 の増 加は，参加率 1\%，5\%，10\%，20\%に対してはそ れぞれ 0.6, 3.0, 5.5, 9.2 ポイントの増加をもたらす.

\section{参考文献}

1 ) Kelly, J. R. and Warnick, R. B. Recreation Trends and Markets: The 21st Century, Sagemore Publishing, Champaign, IL, 1999.

2）財団法人 余暇開発センター.レジャー白書 '89, 1989.

3 ）財団法人 余暇開発センター.レジャー白書 '96, 1996.

4）財団法人 余暇開発センター.レジャー白書 $2000,2000$.

5）財団法人 自由時間デザイン協会. レジャー 白書 2002, 2002.

6）山本達三, 菊池秀夫, 中村隆。スポーツ参加 率の年齢・時代・コウホート効果の分離, 日 本体育・スポーツ経営学会第 24 回大会号, pp.48-49, 2001.

7 ）山本達三, 菊池秀夫, 中村隆. コウホート分 析によるスポーツ参加人口の将来推計, スポー ツ産業学研究第 10 回学会大会号, pp.33-36, 2001.

8 ）山本達三, 菊池秀夫, 中村隆. スポーツ参加 人口の推定と予測一年齢・時代・コウホート 効果・人口変動を考慮して一, スポーツ産業 学研究, 12-2, pp.33-46, 2002.

9 ) 中村隆, 菊池秀夫, 山本達三. スポーツ・レ クリエーション参加のコウホート分析, 統計 数理研究所共同研究リポート 160, pp.1-84, 2003.

10) Loy, J. W., McPherson, B. D., and Kenyon, G. S. Sport and Social Systems, Reading Mass, AddisonWesley, 1978.

11) Yu, J. M. A leisure demand projection model,
Leisure Sciences, 4-2, pp.127-142, 1981.

12) Beaman, J. and Do, H. Consumption of outdoor avtivities and interactivity relations : A causalmodel, Recreation Research Review, 10-1, pp.39-48, 1983.

13) Curtis, J., White, P., and McPherson, B. Age and physical activity among Canadian women and men, Findings from longitudinal national survey data, Journal of Aging and Physical Activity, 8, pp.1-19, 2000.

14) Walsh, R. G., John, K. H., McKean, J. R., and Hof, J. G. Comparing long-run forecasts of demand for fish and wildlife recreation, Leisure Sciences, 11, pp.337-351, 1989.

15) Foot, D. K. The age of outdoor recreation in Canada, Journal of Applied Recreation Research, 15-3, pp.159-178, 1990.

16) Murdock, S. H., Backman, K., and et al. Modeling demographic change and characteristics in the analysis of future demand for leisure services, Leisure Sciences, 12, pp.79-102, 1990.

17) Murdock, S. H., Backman, K., and et al. The implications of change in population size and composition on future participation in outdoor recreational activities, Journal of Leisure Research, 23, 3, pp.238-259, 1991.

18) Jackson, E. L. and Dunn, E. Integrating ceasing participation with other aspects of leisure behavior, Journal of Leisure Research, 20-1, pp.31-45, 1988.

19) Searle, M. S. and Brayley, R. E. Integrating ceasing participation with other aspects of leisure behavior a replication and extension, Journal of Leisure Research, 25-4, pp.389-404, 1993.

20) Iso-Ahola, S. E., Jackson, E., and Dunn, E. Starting, ceasing, and replacing leisure activities over the life-span, Journal of Leisure Research, 26-3, pp.227-249, 1994.

21) Strain, 1. A., Grabusic, C. C., Searle, M. S., and Dunn, N. J. Continuing and ceasing leisure activities in later life: a longitudinal study, The Gerontologist, 42-2, pp.217-223, 2002.

22）長ヶ原誠. 中高齢者の身体活動参加の研究動 向, 体育学研究, 48, pp.245-268, 2003.

23）高峰修, 守能信次. 年齢層別にみた中高年 ウォーキング実施者の特性, 一スポーツ実施 者との比較を通じて一, 東海保健体育科学, 
23, pp.41-48, 2001.

24）勝浦正樹. スポーツの年齢パターン, 統計, 4 月号, pp.37-43, 2003.

25) Brown, T. L. and Wilkins, B. T. Method of improving recreation projections, Journal of Leisure Research, 7, pp.225-234, 1975.

26) Snepenger, D. J. and Ditton R. B. A longitudinal analysis of nationwide hunting and fishing indicators: 1955-1980, Leisure Sciences, 7-3, pp.297-319, 1985.

27) Foot, D. K. and Hennigar, T. W. Recreation and the Economic Cycle in Ontario. Journal of Applied Recreation Research, 17-1, pp.37-62, 1992.

28）永山貞則. 旅行と趣味の年齢パターン, 統計, 4 月号, pp.29-35, 2003.

29) McGuire, F. A., Dottavio, F. D., and O'Leary, J. T. The relationship of early life experiences to later life leisure involvement, Leisure Sciences, 9, pp.251-257, 1987.

30) O'Leary, J. T., Behrens-Tepper, J., McGuire, F. A., and Dottavio, F. D. Age of first hunting experience : Results from a nationwide recreation survey, Leisure Sciences, 9, pp.225-233, 1987.

31）原田宗彦, 長積仁. 高齢者のスポーツ参加に 関する縦断的研究, 自由時間研究, 7, pp.2-10, 1990.

32）北村薰. ライフコース分析と社会化, 教育社 会学研究, 46, pp.35-51, 1990.

33）藤本淳也，原田宗彦．中高年齢者の余暇活動 参加パターンに関する研究, レクリエーショ ン研究, 24, pp.1-8, 1993.

34）海老原修. 高齢者のスポーツ参加動向とスポー ツ・プログラムの作成，（ed. 宮下充正，武藤 芳照.）高齢者とスポーツ, 東京大学出版会, 東京, pp.87-94, 1986.

35) Verbrugge, M. L., Gruber-Baldini, L. A., and Fozard, L. J. Age differences and age changes in activities, Baltimore longitudinal study of aging, Journal of Gerontology, Social Sciences, 51B, 1, pp.S30-S41, 1996.

36) Bijnen, C. H. F., Feskens, J. M. E. and Casperson, J. C., et. al. Age, period, and cohort effects on physical activity among elderly men during 10 years of follow-up, The Zutphen elderly study, Journal of Gerontology, Medical Sciences, 53A No3, pp.M235-M241, 1998.

37）寺崎康博. コーホート分析からみたスポー ツ及び趣味・娛楽活動, 統計, 9-16,7 月号, 2001.

38）多々納秀雄, 徳永幹雄, 金崎良三, 橋本公雄. スポーツ種目のパターン分析と関連要因の分 析, 体育学研究, 26-4, pp.269-289, 1982.

39) Akaike, H. Likelihood and the Bayes procedure, Bayesian Statistics (eds. J. M. Bernardo, M. H. DeGroot, D. V. Lindley and A. F. M. Smith), University Press, Valencia, pp.143-166, 1980.

40）中村隆. ベイズ型コウホート・モデルー標準 コウホート表への適用一, 統数研彙報, 29 , pp.77-97, 1982.

41) Nakamura, T. Bayesian cohort models for general cohort table analyses, Ann. Inst. Statist. Math., 38, Part B, pp.353-370, 1986.

42）中村隆. 質問項目のコウホート分析ー多項口 ジット・コウホートモデルー, 統計数理 , 48, pp.93-119, 2000.

43）中村隆. コウホート分析における交互作用効 果モデル再考, 統計数理, 53(1), pp.103-132, 2005.

44）坂元慶行, 石黒真木夫, 北川源四郎. 情報量 統計学, 共立出版, 東京, 1983 .

45）人口動態統計月報年計（概数）の概況，厚生 労動省大臣官房統計情報部, 2001.

46) Beaman, J., Kim, Y., and Smith, S. The effect of recreation supply on participation, Leisure Sciences 2-1, pp.71-87, 1979.

47）社団法人日本テニス事業者協会. 新たなテニ ス愛好者創出を目的とした革新的会員制度な らびに利用システム，および料金体系策定の ための調査研究, 平成 11 年度中小企業活路開 拓調查事業, 1999.

48）文部省体育局。我が国の体育・スポーツ施設 一体育・スポーツ施設現況調查報告一, 1998.

49）金森久雄，荒憲治郎，森口親司（1998）経済 辞典. 有斐閣 : 東京. 